\title{
Molecular epidemiology of hepatitis A outbreaks in two districts in Indonesia in 2018: Same subtype, but different strains
}

\author{
DEWI SETYOWATI ${ }^{1}$, TEGUH MUBAWADI ${ }^{2}$, YUDIED AGUNG MIRASA ${ }^{2}$, DIDIK PURWANTO $^{2}$, \\ MOCHAMAD AMIN $^{3}$, TAKAKO UTSUMI ${ }^{3,4}$, SOETJIPTO SOETJIPTO ${ }^{1,3}$, \\ JUNIASTUTI JUNIASTUTI ${ }^{1,3}$ and MARIA INGE LUSIDA ${ }^{1,3}$ \\ ${ }^{1}$ Faculty of Medicine, Airlangga University, Surabaya, East Java 60131; ${ }^{2}$ Regional Center for Environmental Health \\ and Disease Control of Surabaya, Surabaya, East Java 60175; ${ }^{3}$ Institute of Tropical Disease, Airlangga University, \\ Surabaya, East Java 60115, Indonesia; ${ }^{4}$ Center for Infectious Diseases, Kobe University Graduate School of Medicine, \\ Kobe, Hyogo 650-0017, Japan
}

Received June 10, 2019; Accepted October 18, 2019

DOI: $10.3892 /$ br.2019.1261

\begin{abstract}
The present study aimed to analyse molecular epidemiological data from hepatitis A virus (HAV) outbreaks in two affected areas. The association between the knowledge of hepatitis A and incidence of infection was also determined. Serum samples were obtained from 88 individuals with clinical manifestations of acute hepatitis in Lamongan $(n=54)$ in January 2018 and Bangkalan $(n=34)$ in March 2018. The outbreak investigation was started one day after the outbreaks were reported by the Public Health Offices in Lamongan and Bangkalan. Anti-HAV immunoglobulin M (IgM) and PCR amplification products of the VP1 capsid protein-P2A protease and VP1-VP3 junctions were analysed. Positive PCR products were sequenced, and a phylogenetic tree was constructed using Molecular Evolutionary Genetics Analysis X software. The control group comprised healthy students and staff members from the two affected areas. Thus, 172 responses from the control and hepatitis A case groups were analysed to assess the association between the students' knowledge level and the incidence of HAV infection. A total of $32(59.25 \%)$ of the 54 individuals from Lamongan and 19 $(55.9 \%)$ of the 34 participants from Bangkalan were positive for anti-HAV IgM; 26 PCR tests were positive in the VP3-VP1 and/or VP1-P2A junction, which were identified as HAV subgenotype IA. The subtype of HAV in the two areas was IA, similar to those identified previously, but the viruses did
\end{abstract}

Correspondence to: Professor Maria Inge Lusida, Institute of Tropical Disease, Airlangga University, Campus C, Jalan Mulyorejo, Surabaya, East Java 60115, Indonesia

E-mail: ingelusida@itd.unair.ac.id

Abbreviations: HAV, hepatitis A virus; IgM, immunoglobulin M; RT-PCR, reverse transcription-PCR

Key words: hepatitis A, knowledge, outbreak, Indonesia, subtype, 2018 not originate from the same strain, as identified by multiple alignment. The knowledge level of the students and staff members in Lamongan studying and working at a half-day school exhibited a significant association with the incidence; however, no association was observed among the students in Bangkalan studying at a full-day school with a dormitory.

\section{Introduction}

Hepatitis A virus (HAV) infection, which is a major cause of acute hepatitis, poses an important public health problem worldwide (1-3). The virus can spread through the faecal-oral route, e.g. ingestion of contaminated food and water or direct contact with an infected person $(4,5)$. The manifestation can be asymptomatic or symptomatic, ranging between mild and fulminant hepatitis, which is rare $(6,7)$. Lack of safe water, as well as poor sanitation and hygiene are risk factors for HAV infection. Epidemics can be prolonged and cause substantial economic loss (7-10).

HAV belongs to the family Picornaviridae and the genus Hepatovirus. HAV contains a $7.5 \mathrm{~kb}$ genome encoded by a positive-sense, single-stranded RNA. HAV has six genotypes (I-VI); genotypes I-III are infectious to humans $(7,11)$. The nucleotide variation between isolates of different genotypes is $\sim 15 \%$, and variation between subgenotypes ranges between 7 and $7.5 \%$ in the VP1 capsid protein-P2A protease junction (7,12-15). Previous studies have demonstrated that the HAV genotype present in Indonesia is IA (16-18).

Outbreaks of hepatitis A in Indonesia have been consecutively reported in the following cities: Bogor (West Java) in 1998 , Jember and Bondowoso (East Java) in 2006, Tangerang (West Java) in 2007, Yogyakarta (Special Region of Yogyakarta) in 2008, Ngawi (East Java) in 2009, Lamongan and Bangkalan (East Java) in 2018 and Pacitan (East Java) in 2019 according to the Sub-directorate of Surveillance and Outbreak Response, Directorate General of Disease Control and Environmental Health, Ministry of Health (personal communication) (17).

The present study focused on the recent hepatitis A outbreaks at a senior high school in Lamongan and at a boarding school in Bangkalan in East Java in 2018. Habits, 
attitude and knowledge level may serve a role in the incidence of hepatitis $\mathrm{A}$ in affected regions. Indonesia is a country with high endemicity of hepatitis A, but genetic information on HAV is still limited. The aim of the present study was to obtain molecular epidemiological data on HAV-caused outbreaks in the two affected areas. The knowledge and incidence of hepatitis A infection were also analysed.

\section{Materials and methods}

Study population. This study was an observational and cross-sectional study. Serum samples were obtained from 88 individuals with clinical manifestations of acute hepatitis in Lamongan $(n=54)$ in January 2018 and Bangkalan $(n=34)$ in March 2018, with a mean age of 16 years (range, 15-55 years). The inclusion criterion of case group was a clinical manifestation of hepatitis, such as fever, sweating, headache, malaise, flatulence, nausea, vomiting, lack of appetite, heartburn, jaundice and dark-coloured urine. The subjects did not receive any drug treatments that may have affected the results of the study. No antiviral treatments were administered. The outbreak investigation was started one day after the outbreak was reported by the Public Health Offices in Lamongan and Bangkalan. A senior high school in Lamongan, termed 'affected area I' in this study, is a half-day school, and the students return home every day after school time. 'Affected area II' is a full-day boarding school in Bangkalan, where students live in a dormitory in the school area.

HAV serological test. The serum samples were screened for IgM anti-HAV using a SD BIOLINE HAV IgG/IgM rapid test (Standard Diagnostics, Inc.) according to the manufacturer's instructions.

RNA extraction and reverse transcription $(R T)-P C R$ amplification. Viral RNA was extracted from $140 \mu \mathrm{l}$ serum using a QIAamp viral RNA mini kit (Qiagen $\mathrm{GmbH}$ ) according to the manufacturer's instructions. The purified RNA samples were used to generate cDNA using ReverTra Ace ${ }^{\circledR}$ (Toyobo Co., Ltd.) according to the manufacturer's instructions. The VP1-P2A and VP3-VP1 junctions were amplified using RT-PCR. The primers are presented in Table I (17-19). The primers for the VP1-P2A region were the basic region (BR)-5 and BR-9 primers for first-round PCR and the RJ-3 and BR-6 primers for second-round PCR. The primers for the VP3-VP1 region were the HAV1 and HAV2 primers for the first-round PCR and the HAV3 and HAV4 primers for the second-round PCR. The thermocycling conditions for the HAV1 and HAV2 primers were as follows: $5 \mathrm{~min}$ at $94^{\circ} \mathrm{C} ; 40$ cycles of $30 \mathrm{sec}$ at $94^{\circ} \mathrm{C}, 30 \mathrm{sec}$ at $57^{\circ} \mathrm{C}$ and $45 \mathrm{sec}$ at $72^{\circ} \mathrm{C}$; and $7 \mathrm{~min}$ at $72^{\circ} \mathrm{C}$. The thermocycling conditions for HAV3 and HAV4 were as follows: $5 \mathrm{~min}$ at $94^{\circ} \mathrm{C}$; 40 cycles of $30 \mathrm{sec}$ at $94^{\circ} \mathrm{C}, 30 \mathrm{sec}$ at $55^{\circ} \mathrm{C}$ and $45 \mathrm{sec}$ at $72^{\circ} \mathrm{C}$; and $7 \mathrm{~min}$ at $72^{\circ} \mathrm{C}$. The thermocycling conditions of the first and second rounds of PCR in the VP1-P2A region using the BR-5 and BR-9 primers and the RJ-3 and BR-6 primers were the same as those of the second-round PCR using the HAV3 and HAV4 primers. A total of $5 \mu \mathrm{l}$ PCR product was analysed using $2 \%$ agarose gel electrophoresis and stained with ethidium bromide to visualize the bands.
Sequence and phylogenetic analysis. The nucleotide sequences of sample HAVs were determined using a BigDye Terminator v3.1 Cycle Sequencing kit (Applied Biosystems; Thermo Fisher Scientific, Inc.) with an Applied Biosystems 3500xL Genetic Analyzer (Thermo Fisher Scientific, Inc.). The results of the sequencing were compared with data from the international DNA databank (GenBank; https://www.ncbi. nlm.nih.gov/genbank/). The GenBank accession numbers used for comparison were as follows: AB020566, KX151445, LC049340, AB020567, AB623053, AF485328, AB839694, AB839693, AB839697, AB839696, AB918714, M14707, AF314208, M20273, AY644676, AY644670, DQ991030, AB279732, FJ360732, AJ299464, JQ655151, AB258387, AB279735, AB425339, M59286, D00924, AF485328, AY294048, DQ114888, AY343856, DQ114866 and AJ519486. Phylogenetic trees were constructed by the neighbour-joining method; to confirm the reliability of phylogenetic tree analysis, bootstrap resampling and reconstruction were performed 1,000 times using the Molecular Evolutionary Genetics Analysis (MEGA) X software (https://www.megasoftware.net/).

Association between subject knowledge of hepatitis A infection and incidence. The pre-designed questionnaire was pre-tested on a group of students not included in the present study and for validation. A self-administered structured questionnaire was used to collect information about the sociodemographic characteristics (age, sex, occupation) and knowledge of HAV including causes, symptoms, transmission, target organ, treatment and prevention (hygiene and sanitation) methods.

Statistical analysis. The samples were divided into two groups, i.e., the control and case groups. The control group included healthy students and staff members in affected areas $I(n=51)$ and II $(n=33)$, whereas the case group included individuals with acute hepatitis in affected areas I $(n=54)$ and II $(n=34)$. A total of 172 samples were included in the statistical analysis. Descriptive data are presented as numbers and percentages. Chi square test was used to analyse the association between knowledge of hepatitis A and the incidence of infection in affected areas I and II. SPSS Statistics for Windows version 22.0 (IBM Corp.) was used for statistical analysis. $\mathrm{P}<0.05$ was considered to indicate a statistically significant difference.

\section{Results}

Subject sex, age, occupation and symptoms in the two affected areas. The characteristics of patients with hepatitis A from the two affected areas are summarized in Table II. Among the 88 subjects enrolled during the outbreaks, more female patients were present in affected area I, whereas more male patients were present in affected area II. Age $\leq 17$ years was predominant in both affected areas. The most prominent symptom was nausea (59\%), accompanied by other symptoms. All participants from the two affected areas were tested for Anti-HAV IgM, HAV-RNA detection, and their serum samples were subjected to sequencing. The results revealed that all 18 strains belonged to the HAV IA subtype. The workflow and results obtained from the genetic analysis are presented in Fig. 1. 
Table I. Primers used for HAV RNA amplification.

\begin{tabular}{|c|c|c|c|c|}
\hline Region & Primers & Sequences $\left(5^{\prime}-3^{\prime}\right)$ & Nucleotide no. & Product size, bp \\
\hline \multirow[t]{4}{*}{ VP1-P2A } & BR-5 & TTGTCTGTCACAGAACAATCAG & $2950-2972$ & 361 \\
\hline & BR-9 & AGTCACACCTCTCCAGGAAAACTT & $3310-3286$ & \\
\hline & RJ-3 & TCCCAGAGCTCCATTGAA & 2984-3002 & 234 \\
\hline & BR-6 & AGGAGGTGGAAGCACTTCATTTGA & $3217-3193$ & \\
\hline \multirow[t]{4}{*}{ VP3-VP1 } & HAV1 & GCTCСТCTTTATCATGCTATGGAT & $2172-2196$ & 244 \\
\hline & HAV2 & CAGGAAATGTCTCAGGTACTTTCT & $2415-2391$ & \\
\hline & HAV3 & ATGTTAACTACACAAGTTGGAGAT & $2195-2218$ & 186 \\
\hline & HAV4 & GATCCTCAATTGTTGTGATAGCT & $2380-2357$ & \\
\hline
\end{tabular}

Table II. Characteristics of patients in the two affected areas.

\begin{tabular}{|c|c|c|c|c|}
\hline \multirow[b]{2}{*}{ Characteristics } & \multicolumn{2}{|c|}{$\begin{array}{c}\text { Affected area } \\
\quad I(n=54)\end{array}$} & \multicolumn{2}{|c|}{$\begin{array}{c}\text { Affected area } \\
\text { II }(n=34)\end{array}$} \\
\hline & $\mathrm{n}$ & $\%$ & $\mathrm{n}$ & $\%$ \\
\hline \multicolumn{5}{|l|}{ Sex } \\
\hline Female & 35 & 65 & 6 & 18 \\
\hline Male & 19 & 35 & 28 & 82 \\
\hline \multicolumn{5}{|l|}{ Age, years } \\
\hline$\leq 17$ & 33 & 61 & 16 & 47 \\
\hline $18-25$ & 5 & 9 & 12 & 35 \\
\hline $26-45$ & 10 & 19 & 6 & 18 \\
\hline$\geq 46$ & 6 & 11 & 0 & 0 \\
\hline \multicolumn{5}{|l|}{ Occupation } \\
\hline Student & 34 & 63 & 27 & 79 \\
\hline Teacher & 8 & 15 & 3 & 9 \\
\hline Chef & 12 & 22 & 4 & 12 \\
\hline \multicolumn{5}{|l|}{ Symptoms } \\
\hline Fever & 23 & 43 & 18 & 53 \\
\hline Sweating & 7 & 13 & 14 & 41 \\
\hline Headache & 21 & 39 & 10 & 29 \\
\hline Malaise & 13 & 24 & 12 & 35 \\
\hline Flatulence & 14 & 26 & 13 & 38 \\
\hline Nausea & 32 & 59 & 16 & 47 \\
\hline Vomiting & 24 & 44 & 10 & 29 \\
\hline Lack of appetite & 28 & 52 & 14 & 41 \\
\hline Heartburn & 13 & 24 & 19 & 56 \\
\hline Jaundice & 27 & 50 & 15 & 44 \\
\hline Dark-coloured urine & 23 & 43 & 10 & 29 \\
\hline
\end{tabular}

Prevalence of anti-HAV IgM. Serum samples with clinically suspected hepatitis A were tested for the presence of anti-HAV IgM. Among the patients from affected areas I and II, 32 of 54 $(59.25 \%)$ and 19 of 34 (55.9\%), respectively, were positive for anti-HAV IgM.

HAV RNA analysis. The VP3-VP1 and VP1-P2A junction regions were amplified from all anti-HAV IgM-positive and negative serum samples. The HAV RNA analysis of the VP3-VP1 junction was positive in 8 of 54 and 6 of 34 patients from affected areas I and II, respectively. The analysis of
Outbreaks

Affected area I (54) and II (34)

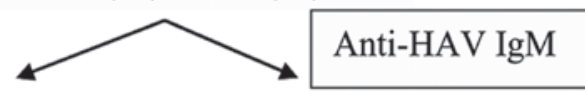

$32 / 54$ and $19 / 34$ positive

$22 / 54$ and $15 / 34$ negative

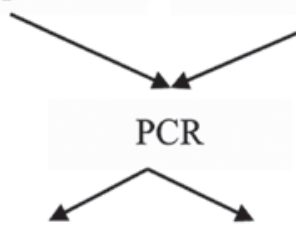

$26 / 88$ positive $\quad 62 / 88$ negative

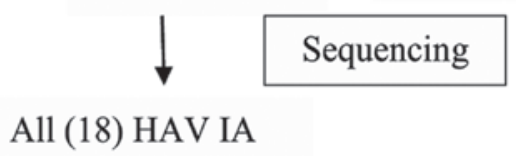

Figure 1. Workflow with the results of genetic analysis. HAV, hepatitis A virus; IgM, immunoglobulin $\mathrm{M}$.

the VP1-P2A junction was positive in 16 of 54 patients from affected area I and in 2 of 34 patients from affected area II. A total of 26 patients were HAV RNA-positive in either the VP3-VP1 or VP1-P2A junction.

Sequencing and phylogenetic analyses

VP1-P2A region. A total of seven nucleotide sequences of HAV strains obtained in the present study, of which six were from affected area I and one was from affected area II, were 99-100\% identical to each other in the VP1-P2A region and were closely related to the HAV subgenotype IA. Samples from affected area I exhibited $100 \%$ homology with a strain with the accession number AB918714 (SurabayaIndonesia) (Fig. 2).

VP3-VP1 region. A total of 11 nucleotide sequences of HAV strains obtained in the present study, including seven samples from affected area I and four samples from affected area II, were $99 \%$ identical to each other in the VP3-VP1 junction region sequence and were closely related to $\mathrm{HAV}$ strains of subgenotype IA (Fig. 3). 
Table III. Knowledge of hepatitis A in infected (case) and control groups.

Affected area I

Affected area II

\begin{tabular}{|c|c|c|c|c|c|c|c|c|}
\hline \multirow{2}{*}{$\begin{array}{l}\text { Knowledge } \\
\text { level }\end{array}$} & \multicolumn{2}{|c|}{ Control $(n=51)$} & \multicolumn{2}{|c|}{ Case $(n=54)$} & \multicolumn{2}{|c|}{ Control (n=33) } & \multicolumn{2}{|c|}{ Case $(n=34)$} \\
\hline & $\mathrm{n}$ & $\%$ & $\mathrm{n}$ & $\%$ & $\mathrm{n}$ & $\%$ & $\mathrm{n}$ & $\%$ \\
\hline High & 43 & 84 & 21 & 39 & 18 & 55 & 19 & 56 \\
\hline Moderate & 7 & 14 & 22 & 41 & 14 & 42 & 12 & 35 \\
\hline Low & 1 & 2 & 11 & 20 & 1 & 3 & 3 & 9 \\
\hline
\end{tabular}

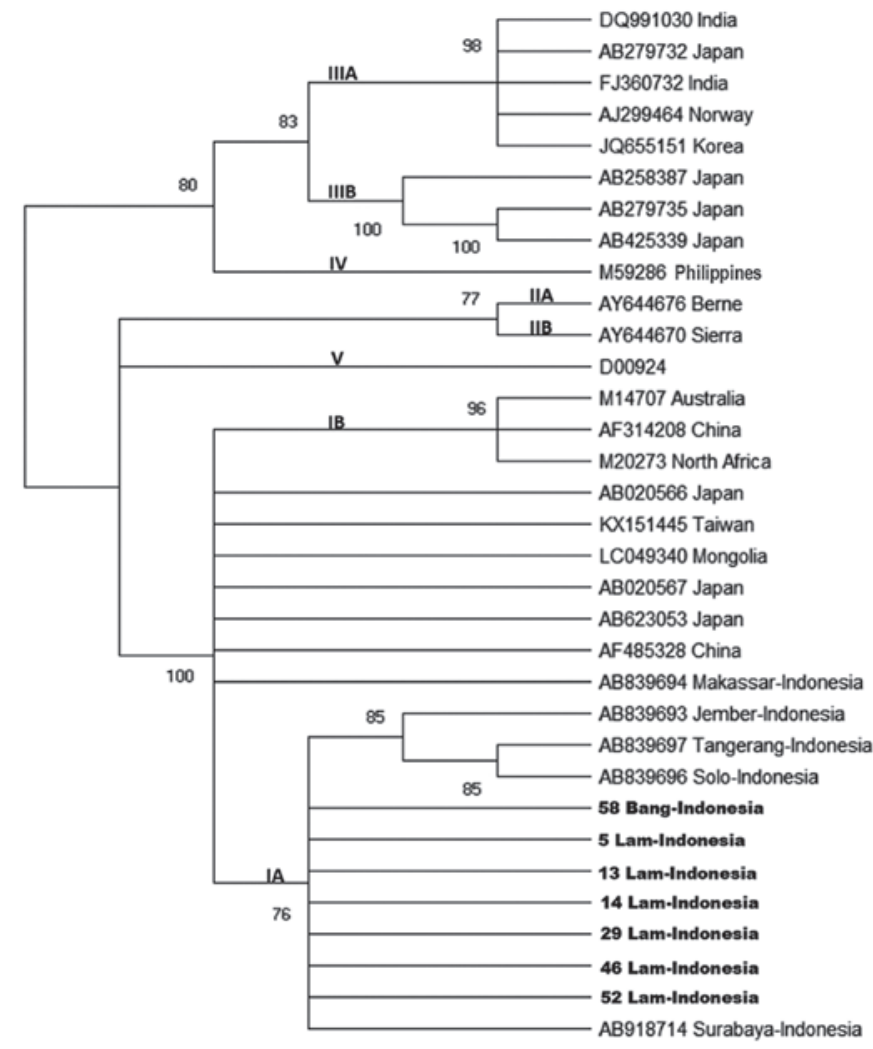

Figure 2. Phylogenetic tree generated using the nucleotide sequences obtained from the VP1-P2A junction region. HAV strains isolated from Lam (affected area I) and Bang (affected area II) (number of samples presented) and 26 reported HAV isolates of genotypes/subgenotypes IA, IB, IIA, IIB, IIIA, IIIB, IV and V with complete or nearly complete sequences are included for comparison. Numbers in the tree indicate bootstrap reliability. The length of each horizontal bar indicates the number of nucleotide substitutions per site. Isolates from the Genbank database are indicated by the accession number, and relevant (town and) country names have been listed for each HAV strain. HAV, hepatitis A virus; Lam, Lamongan; Bang, Bangkalan.

Alignment of amino acid sequences. The predicted amino acid sequences of the VP1-P2A and VP3-VP1 regions from the samples collected in the present study were compared with those from previously reported strains (Figs. 4 and 5). Representative HAV isolates of all genotypes and subgenotypes are described in Figs. 4 and 5. Although all affected area I and II strains belonged to subgenotype IA, the samples from affected area II had amino acids that were not present in any other strain from area I, i.e., K813N in the VP1-P2A junction and M519T in the VP3-VP1 junction.

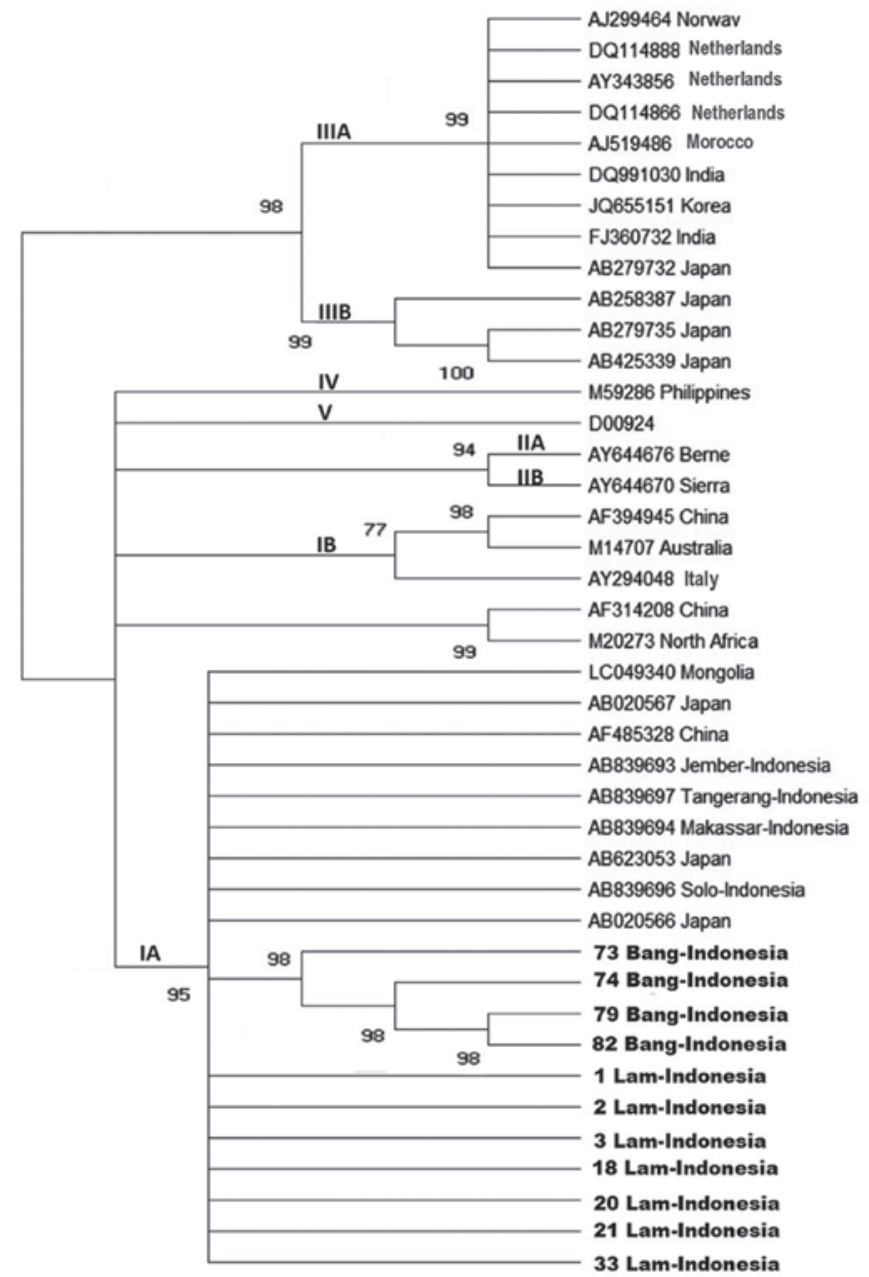

Figure 3. Phylogenetic tree generated using the nucleotide sequences obtained from the VP3-VP1 junction region. HAV strains isolated from Lam (affected area I) and Bang (affected area II) (number of samples presented) and 30 reported HAV isolates of genotypes/subgenotypes IA, IB, IIA, IIB, IIIA, IIIB, IV and V with complete or nearly complete sequences are included for comparison. Numbers in the tree indicate bootstrap reliability. The length of each horizontal bar indicates the number of nucleotide substitutions per site. Isolates from the Genbank database are indicated by their accession number, and relevant (town and) country names have been listed for each HAV strain. HAV, hepatitis A virus; Lam, Lamongan; Bang, Bangkalan.

Association between knowledge level of subjects and incidence of hepatitis A infection. The knowledge level was divided into three categories; the category 'high' included responses with $>75 \%$ correct answers, 'moderate' included responses with 50 to $74 \%$ correct answers and 'low' included responses with $<50 \%$ 
Table IV. Association between knowledge level and incidence of hepatitis

\begin{tabular}{|c|c|c|c|c|c|}
\hline \multirow[b]{2}{*}{ Knowledge level } & \multirow[b]{2}{*}{ P-value } & \multicolumn{2}{|c|}{ OR } & \multirow{2}{*}{$\begin{array}{l}\text { Association between variables } \\
\text { (incidence of hepatitis A infection) }\end{array}$} & \multirow[b]{2}{*}{$\alpha(\mathrm{CI}=95 \%$} \\
\hline & & Low-high & Low-moderate & & \\
\hline Affected area I & $0.001^{\mathrm{a}}$ & 22.523 & 3.5 & $42.8 \%$ & 0.05 \\
\hline Affected area II & 0.558 & - & - & $13.1 \%$ & \\
\hline
\end{tabular}

${ }^{\mathrm{a}} \mathrm{P}<0.005$; OR, odds ratio; CI, confidence interval.

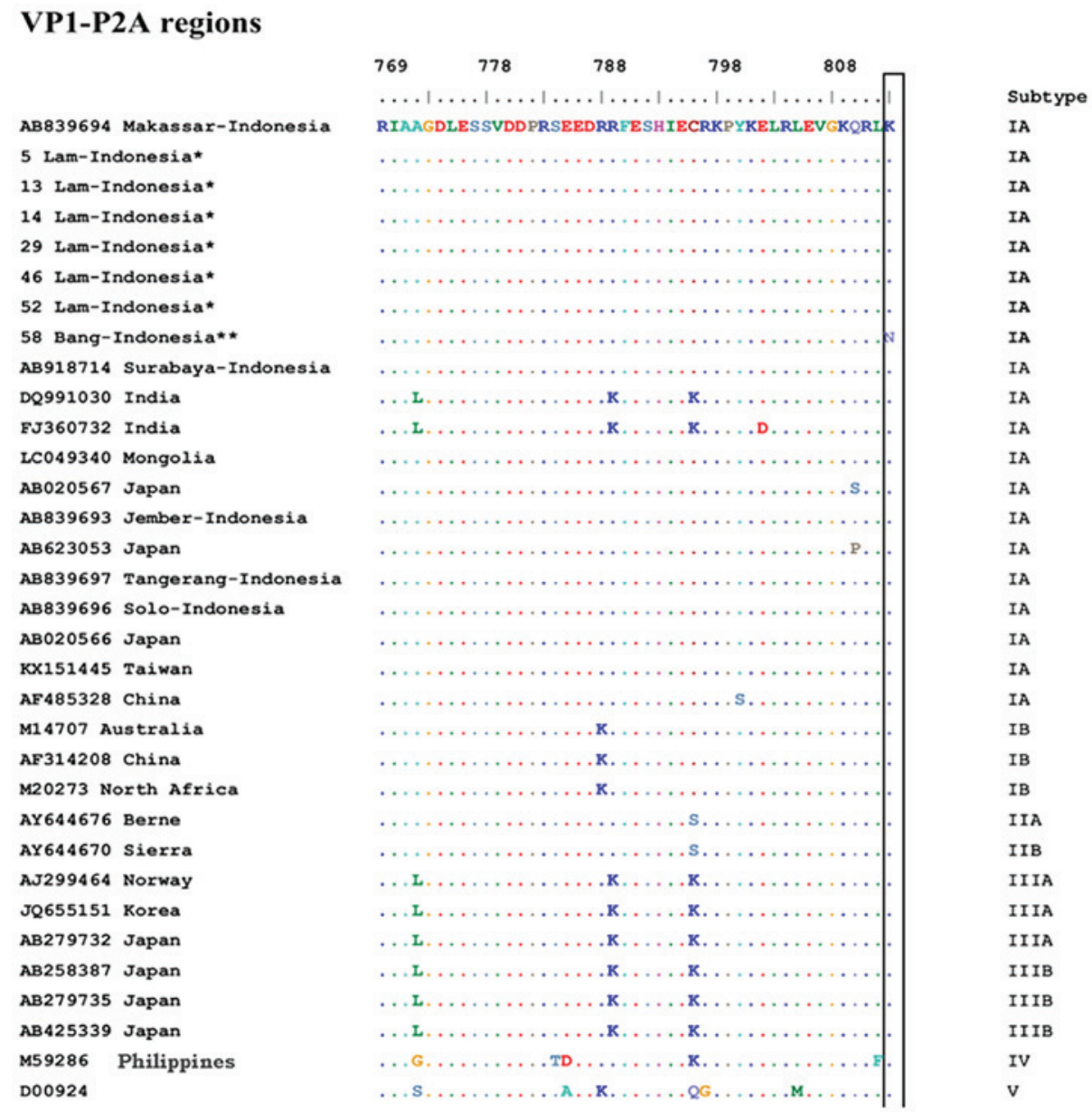

Figure 4. Comparison of the predicted amino acid sequences of the VP1-P2A junction region. The consensus amino acid sequence for the predominant subgenotype IA is presented in the top row. Dots indicate conserved amino acids; differences are indicated by the single-letter amino acid code. The numbers above the consensus amino acid sequence indicate the predicted amino acid number from the start of full-length HAV. The genotype/subtype of the HAV strains is indicated on the right. Seven isolates of subgenotype IA obtained in the present study are indicated by asterisks and presented in bold; " samples from Lamongan; ** samples from Bangkalan. HAV, hepatitis A virus; Lam, Lamongan; Bang, Bangkalan.

correct answers. The distribution of knowledge of the subjects was mainly high (84\%) in the control group and moderate (41\%) in the case group in affected area I. In affected area II, the knowledge was high in 55\% of the control group and $56 \%$ in the case group. The distribution of knowledge of the subjects in the present study is presented in Table III. The association between knowledge level and the incidence of hepatitis A infection is presented in Table IV. Significant differences were observed in the level of knowledge and the incidence of Hepatitis A in affected area $\mathrm{I}(\mathrm{P}=0.001)$, whereas the knowledge of students in affected area II was not associated with incidence.

\section{Discussion}

The present study determined and analysed the genomic sequence of HAV isolates from the Lamongan and Bangkalan hepatitis A outbreak areas in 2018. The major advantage of this study was the acquired genetic information of HAV from the latest outbreaks in two affected areas. The subtype of HAV in the two studied affected areas was IA, similar to those previously identified (16-18), although the viruses did not originate from the same strain. Lamongan and Bangkalan are cities $\sim 109 \mathrm{~km}$ apart on two different islands. Of the 88 patients 


\section{VP3-VP1 region}
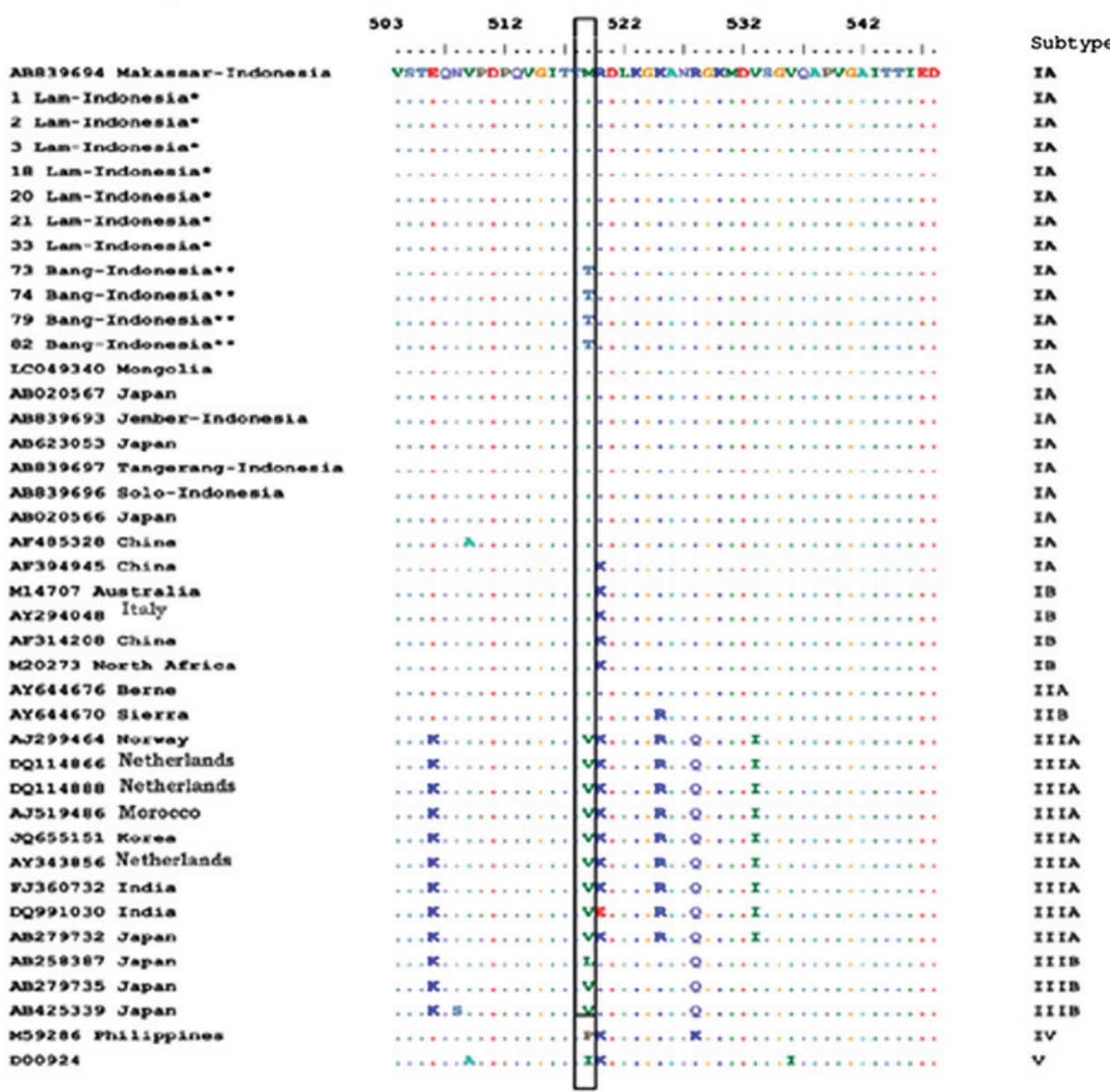

Figure 5. Comparison of the predicted amino acid sequences of the VP3-VP1 junction region. The consensus amino acid sequence for the predominant subgenotype IA is presented in the top row. Dots indicate conserved amino acids; differences are indicated by the single-letter amino acid code. The numbers above the consensus amino acid sequence indicate the predicted amino acid number from the start of full-length HAV. The genotype/subtype of the HAV strains is indicated on the right. Eleven isolates of subgenotype IA obtained in the present study are indicated by asterisks and presented in bold; "samples from Lamongan; *"samples from Bangkalan. HAV, hepatitis A virus; Lam, Lamongan; Bang, Bangkalan.

suspected to have hepatitis A from the two affected areas, 51 were positive for anti-HAV IgM and 26 exhibited positive PCR results in the VP3-VP1 and/or VP1-P2A region. Anti-HAV $\operatorname{IgM}$ is a routine laboratory diagnostic test for hepatitis A (20). Anti-HAV IgM is detectable at or prior to the onset of clinical symptoms, and the levels decline in 3 to 6 months (11). Of note, acute hepatitis A may also occur without the production of detectable IgM antibodies (21). In the present study, cases of acute HAV infection were be diagnosed by detection of HAV RNA; this molecular marker is detectable $\sim 14$ days prior to the appearance of the acute-phase serological markers and remains persistently detectable for an average of 79 days following symptom onset and peak hepatic enzyme levels (7,20-22). The establishment of early laboratory diagnosis of HAV infection is important for the guidance and implementation of measures for the prevention and control of outbreaks. Rapid tests have been widely used as screening tools in developing countries $(5,23)$.

Viral genotypic profiles are required to identify foodborne outbreaks, implement preventative measures and recognize transmission routes $(3,24-26)$. The VP1 region of HAV is an area that contains variable amino acids, which is why this region was used as one of the areas for molecular detection in the present study $(19,27)$. Amplification and sequencing of variable regions within the capsid proteins, including the VP3/VP1 and VP1/P2A junctions of wild-type HAV isolates from different regions of the world, revealed significant nucleotide sequence heterogeneity, but limited amino acid heterogeneity (28). These junctions have been used in the analyses of a number of sequences, especially for comparing sequences of isolates obtained from several countries $(17,18,28-31)$. The results of the present study demonstrated that the HAV genotype of all strains in affected areas I and II belonged to subgenotype IA, although the causative strain of HAV in affected area I was different from that identified in affected area II. This result was similar to that of our previous study and other studies from other regions in Indonesia, which identified clustering with genotype IA strains (16-18).

Worldwide, genotype I is the most prevalent, with subtype IA more common compared with IB. As subgenotype IA is prevalent, genotyping/subgenotyping alone can rarely be utilized to identify the source of an HAV outbreak or the chain of transmission $(1,11)$. The HAV isolates that have been identified thus far display a high degree of genetic conservation, and modest genetic heterogeneity exists in several genomic regions, 
with the exception of the 5' untranslated region, which has demonstrated high levels of conservation, supporting the use of RT-PCR for the sensitive detection of HAV RNA $(1,3,11,32,33)$.

Amino acid sequences of VP3-VP1 were compared with diverse subgenotype strains reported in various countries, and all samples from affected area II were identified to contain a unique amino acid, M519T, compared with those from affected area I and other reported IA strains from the DNA Data Bank. The samples from affected area II also had a unique amino acid, K813N, in VP1-P2A, whereas samples from affected area I did not exhibit K813 mutations, similar to previous reports from Indonesia and other countries $(27,34,35)$. Thus, although these epidemics in the two areas occurred at a similar time and the causative epidemic agents were HAV-IA, they were different strains of HAV.

The results of the questionnaire on hepatitis A infection in relation to hygiene in affected area I revealed that the control group possessed a high level of knowledge of hepatitis A, whereas the case group exhibited a moderate level of knowledge. In affected area II, the control and case groups possessed a high level of knowledge. No statistically significant differences were observed in the level of knowledge and the incidence of hepatitis A. Investigations on the two affected area found that poor hygiene and sanitation in canteens (no available washbasins) and the close proximity of septic tanks to wells may have contributed to the spread of HAV. It may be assumed that in affected area II, these facilities were used by all occupants; thus, when infection was present, it could spread quickly. By contrast, in affected area I, the students had a choice of facilities and did not live together in a dormitory, which may have reduced the risk of transmission of hepatitis A infection. Therefore, the level of knowledge in affected area II did not affect behaviours to avoid hepatitis A infection. This result is similar to that of another study (36), which indicated that although public awareness was high, practical knowledge regarding differences in the mode of transmission, consequences and prevention was low in highly endemic countries, especially among those with a lower level of education. Additionally, no differences were observed in the prevention of hepatitis in an intervention group (37). Age, sex and geographic location are not associated with the level of knowledge and practice to avoid hepatitis A infection $(37,38)$.

The limitation of the present study was that clinical symptoms rather than laboratory tests were used as inclusion criteria for the control groups; further studies with larger samples are needed to acquire more information about HAV in the affected areas.

\section{Acknowledgements}

Not applicable.

\section{Funding}

This study was funded by the Progam Pendidikan Magister Menuju Doktor Untuk Sarjana Unggul (PMDSU) Batch III of the Ministry of Research, Technology and Higher Education of the Republic of Indonesia (grant no. 134/UN3.14/LT/2018), in part by The Japan Initiative for Global Research Network on Infectious Diseases (J-GRID) programme from the Ministry of Education, Culture, Sports, Science, and Technology (MEXT),
Japan, and in part by a Grant in Aid from Dato' Sri Professor Dr Tahir through the Tahir Professorship Program, Indonesia.

\section{Availability of data and materials}

The datasets used and/or analysed during the current study are available from the corresponding author on reasonable request.

\section{Authors' contributions}

This study was conducted and designed by MIL, JJ, TU, SS, and DS. TM, YAM, DP and DS performed sample collection. DS, YAM, DP and MA performed the laboratory experiments. DS, JJ, MIL, TU, SS analysed data and wrote the manuscripts. All authors read and approved the final manuscript.

\section{Ethics approval and consent to participate}

The study protocol was approved by the Ethics Committee of the Faculty of Medicine, Airlangga University (Surabaya, Indonesia). The ethical approval number is 158/EC/KEPK/FKUA/2018. All patients provided written informed consent. Informed consent for participations $<18$ years in this study was obtained from the parents of each individual.

\section{Patient consent for publication}

Not applicable.

\section{Competing interests}

The authors declare that they have no competing interests.

\section{References}

1. Vaughan G, Goncalves Rossi LM, Forbi JC, de Paula VS, Purdy MA, Xia G and Khudyakov YE: Hepatitis A virus: Host interactions, molecular epidemiology and evolution. Infect Genet Evol 21: 227-243, 2014.

2. Shin E, Kim JS, Oh KH, Oh SS, Kwon M, Kim S, Park J, Kwak HS, Chung GT, Kim CJ, et al: A waterborne outbreak involving hepatitis A virus genotype IA at a residential facility in the Republic of Korea in 2015. J Clin Virol 94: 63-66, 2017.

3. Quiñones B, Lee BG, Martinsky TJ, Yambao JC, Haje PK and Schena M: Sensitive genotyping of foodborne-associated human noroviruses and hepatitis A virus using an array-based platform. Sensors (Basel) 17: 1-16, 2017.

4. Lin KY, Chen GJ, Lee YL, Huang YC, Cheng A, Sun HY, Chang SY, Liu CE and Hung CC: Hepatitis A virus infection and hepatitis A vaccination in human immunodeficiency virus-positive patients: A review. World J Gastroenterol 23: 3589-3606, 2017.

5. de Almeida Ribeiro CR, Amado LA, Tourinho RS, Pinto Lima LR, Melgaço JG, de Almeida AJ, Bastos LS, Lewis-Ximenez LL and de Paula VS: Accuracy of rapid test for diagnosis of hepatitis A with different infection rate settings and with predictive modeling. Future Microbiol 14: 247-258, 2019

6. Walker BW: Hepatitis A infection: On alert for outbreaks. Nursing 48: 66-69, 2018.

7. Lemon SM, Ott JJ, Van Damme P and Shouval D: Type A viral hepatitis: A summary and update on the molecular virology, epidemiology, pathogenesis and prevention. J Hepatol 68: 167-184, 2017.

8. World Health Organization (WHO): Hepatitis A. https://www. who.int/news-room/fact-sheets/detail/hepatitis-a, 2019.

9. Ouardani I, Turki S, Aouni M and Romalde JL: Detection and molecular characterization of hepatitis A virus from Tunisian wastewater treatment plants with different secondary treatments. Appl Environ Microbiol 82: 3834-3845, 2016. 
10. Walczak-Galezewska MK, Skrypnik D, Szulinska M, Skrypnik K and Bogdanski P: Conservative management of acute calculous cholecystitis complicated by pancreatitis in an elderly woman: A case report. Medicine (Baltimore) 97: e11200, 2018.

11. Nainan OV, Xia G, Vaughan G, and Margolis HS: Diagnosis of hepatitis A virus infection: A molecular approach. Clin Microbiol Rev 19: 63-79, 2006.

12. Ishii K, Kiyohara T, Yoshizaki S, Kawabata K, Kanayama A, Yahata Y, Takahashi T, Kinoshita H, Saitou T, Sunagawa T, et al: Epidemiological and genetic analysis of a 2014 outbreak of hepatitis A in Japan. Vaccine 33: 6029-6036, 2015.

13. Kanda T, Nakamoto S, Wu S, Nakamura M, Jiang X, Haga Y, Sasaki R and Yokosuka O: Direct-acting Antivirals and Host-targeting agents against the hepatitis A virus. J Clin Trans Hepatol 3: 205-210, 2015.

14. McKnight KL, Lemon SM: Hepatitis A virus genome organization and replication strategy. Cold Spring Harb Perspect Med 8: 1-18, 2018.

15. Blanco Fernández MD, Torres C, Riviello-López G, Poma HR, Rajal VB, Nates S, Cisterna DM, Campos RH and Mbayed VA: Analysis of the circulation of hepatitis A virus in Argentina since vaccine introduction. Clin Microbiol Infect 18: E548-E551, 2012.

16. Mulyanto, Wibawa ID, Suparyatmo JB, Amirudin R, Ohnishi H, Takahashi M, Nishizawa $\mathrm{T}$ and Okamoto $\mathrm{H}$ : The complete genomes of subgenotype IA hepatitis A virus strains from four different islands in Indonesia form a phylogenetic cluster. Arch Virol 159: 935-945, 2014.

17. Juniastuti, Dedy WN, Mochamad A, Yamani LN, Utsumi T, Sustini F, et al: Analysis of genetic and serology of hepatitis A virus infection during and after outbreak in two junior high schools in Surabaya, Indonesia. J Med Virol 91: 1048-1055, 2019.

18. Utsumi T, Yano Y, Amin M, Lusida MI, Soetjipto, Hotta H and Hayashi Y: Acute hepatitis due to hepatitis A virus subgenotype IA as an imported infectious disease from Indonesia. Kobe J Med Sci 60: E43-E47, 2014.

19. Yun H, Kim S, Lee H, Byun KS, Kwon SY, Yim HJ, Lim YS Jeong SH and Jee Y: Genetic analysis of HAV strains isolated from patients with acute hepatitis in Korea, 2005-2006. J Med Virol 80: 777-784, 2008.

20. Schwarz NG, Revillion M, Dussaix E, Giraud M, Liberpre C, Couturier E, et al: Surveillance and outbreak reports food-borne outbreak of hepatitis A virus (HAV). Up Normandy. 13: 1-5, 2008.

21. Pondé RAA: The serological markers of acute infection with hepatitis A, B, C, D, E and G viruses revisited. Arch Virol 162: 3587-3602, 2017.

22. Aggarwal R and Goel A: Hepatitis A: Epidemiology in resourcepoor countries. Curr Opin Infect Dis 28: 488-496, 2015

23. Cha YJ, Park Q, Kang ES, Yoo BC, Park KU, Kim JW, Hwang YS and Kim MH: Performance evaluation of the OraQuick hepatitis C virus rapid antibody test. Ann Lab Med 33: 184-189, 2013.

24. Vinjé J: Advances in laboratory methods for detection and typing of norovirus. J Clin Microbiol 53: 373-381, 2015.

25. Verhoef L, Vennema H, van Pelt W, Lees D, Boshuizen H, Henshilwood K and Koopmans M; Food-Borne Viruses in Europe Network: Use of norovirus genotype profiles to differentiate origins of foodborne outbreaks. Emerg Infect Dis 16: 617-624, 2010

26. Verhoef L, Kouyos RD, Vennema H, Kroneman A, Siebenga J, van Pelt W and Koopmans M; Foodborne Viruses in Europe Network: An integrated approach to identifying international foodborne norovirus outbreaks. Emerg Infect Dis 17: 412-418, 2011
27. Bruni R, Taffon S, Equestre M, Chionne P, Madonna E, Rizzo C, Tosti ME, Alfonsi V, Ricotta L, De Medici D, et al; Italian National Task Force on Hepatitis A: Key role of sequencing to trace hepatitis a viruses circulating in Italy during a large multicountry European foodborne outbreak in 2013. PLoS One 11: e0149642, 2016

28. Lee H, Jeong H, Yun H, Kim K, Kim JH, Yang JM and Cheon DS: Genetic analysis of hepatitis A virus strains that induced epidemics in Korea during 2007-2009. J Clin Microbiol 50: 1252-1257, 2012

29. Cristina J and Costa-Mattioli M: Genetic variability and molecular evolution of hepatitis A virus. Virus Res 127: 151-157, 2007.

30. de Paula VS, Lu L, Niel C, Gaspar AMC and Robertson BH: Genetic analysis of hepatitis A virus isolates from Brazil. J Med Virol 73: 378-383, 2004.

31. Chironna M, Grottola A, Lanave C, Villa E, Barbuti S and Quarto M: Genetic analysis of HAV strains recovered from patients with acute hepatitis from Southern Italy. J Med Virol 70: 343-349, 2003.

32. Bruni R, Taffon S, Equestre M, Cella E, Lo Presti A, Costantino A, Chionne P, Madonna E, Golkocheva-Markova E, Bankova D, et al: Hepatitis a virus genotypes and strains from an endemic area of Europe, Bulgaria 2012-2014. BMC Infect Dis 17: 497, 2017

33. Liu GD, Hu NZ and Hu YZ: Full-length genome of wild-type hepatitis A virus (DL3) isolated in China. World J Gastroenterol 9: 499-504, 2003.

34. Hamza H, Abd-Elshafy DN, Fayed SA, Bahgat MM, El-Esnawy NA and Abdel-Mobdy E: Detection and characterization of hepatitis A virus circulating in Egypt. Arch Virol 162: 1921-1931, 2017.

35. Lee AR, Lee SG, Kang LH, Jheong WH and Paik SY: Full-length genomic sequence of subgenotype IIIA hepatitis A virus isolate in Republic of Korea. BioMed Res Int 2013: 426034, 2013.

36. Crutzen R and Göritz AS: Public awareness and practical knowledge regarding Hepatitis A, B, and C: A two-country survey. J Infect Public Health 5: 195-198, 2012.

37. Tenner CT, Herzog K, Chaudhari S, Bini EJ and Weinshel EH: Knowledge, attitudes and barriers regarding vaccination against hepatitis $\mathrm{A}$ and $\mathrm{B}$ in patients with chronic hepatitis $\mathrm{C}$ virus infection: A survey of family medicine and internal medicine physicians in the United States. Int J Clin Pract 66: 1009-1013, 2012.

38. Larios SE, Masson CL, Shopshire MS, Hettema J, Jordan AE, McKnight C, Young C, Khalili M, Seewald RM, Min A, et al: Education and counseling in the methadone treatment setting improves knowledge of viral hepatitis. J Subst Abuse Treat 46: 528-531, 2014.

This work is licensed under a Creative Commons Attribution-NonCommercial-NoDerivatives 4.0 International (CC BY-NC-ND 4.0) License. 